Annals of Warsaw University of Life Sciences - SGGW

Land Reclamation No 41 (2), 2009: 95-107

(Ann. Warsaw Univ. of Life Sciences - SGGW, Land Reclam. 41 (2), 2009)

\title{
Analysis of thermal diffusivity data determined for selected organic topsoil layer
}

\section{TOMASZ GNATOWSKI}

Department of Environmental Improvement, Warsaw University of Life Sciences - SGGW

\begin{abstract}
Analysis of thermal diffusivity data determined for selected organic topsoil layer. Thermal diffusivity $\left(K_{T}\right)$ is a very complex soil property. However, proper estimation of this parameter is very important for the study of thermal processes in the soil. Nevertheless, the thermal diffusivity of peat and organic soils is not well characterized. The purpose of this study was to evaluate different methods for the assessment of the thermal diffusivity of selected organic topsoil layer. The first group of methods included calculation procedures developed from analytical solution of the heat transfer equation. For the determination of thermal diffusivity the distribution of the soil temperature at two depths was required. The second group of methods was based on the classical definition of thermal diffusivity where the quantification of thermal conductivity and heat capacity is required. The measurements and calculations clearly suggest that methods based on the phase equation should be not considered as appropriate methods for thermal diffusivity determination for organic soils. The other methods considered lead to results which were comparable to the experimental $K_{T}$ data.
\end{abstract}

Key words: thermal diffusivity, top soil layer.

\section{INTRODUCTION}

The study of temperature distribution in soil profiles requires a solution of the heat transfer equation. This solution depends on the formulation of the boundary condition as well as the soil thermal properties, which are represented by the thermal diffusivity coefficient $\left(K_{T}\right)$. The $K_{T}$ parameter is commonly defined as a ratio between soil thermal conductivity $(\lambda)$ and soil volumetric heat capacity $\left(C_{v}\right)$.

The apparent thermal diffusivity can be determined under field conditions from soil temperature variations at certain depths (Horton et al. 1983). For this purpose, several methods mainly based on solutions of one-dimensional heat conduction equation with constant $K_{T}$ value are available (Horton et al., 1983; Verhoef et al. 1996, Kossowski and Sikora 1978). These methods are very attractive because only temperature measurements are required. However they are limited for uniform topsoil layers. The $K_{T}$ value based on thermal conductivity and volumetric heat capacity data can also be determined. For quantifying the thermal conductivity of soils the single probe method is often used (Bristow et al. 1994, Abu-Hamdeh 2001). This measurement methodology is classified as a non-steady state method.

For soil volumetric heat capacity the empirical equations can be applied (De Vries, 1963, Hubrechts 1998, Weiss et al. 2006). Thermal properties of mineral soils are widely reported in the literature by De Vries (1963), Jury et al. (1991), 
Usowicz (1992) and Hubrechts (1998). Thermal diffusivity of organic soils and materials were studied by Horton et al. (1983), Usowicz (1996) and Gnatowski et al. (2006). These reported studies, however, indicate that the characterization of the thermal diffusivity of organic soils is relatively limited. Because $K_{T}$ value is related to thermal conductivity and volumetric heat capacity it is a complex property of the soil. Therefore the objective of this study is to determine apparent thermal diffusivity values for selected top organic soil layer using different methods.

\section{METHODS}

The one-dimensional heat transfer equation in an isotropic soil is as follows:

$$
\frac{\delta T}{\delta t}=K_{T} \frac{\delta^{2} T}{\delta z^{2}}
$$

where: $T$ represents soil temperature, $z$ is the depth in the soil profile and $K_{T}$ is the apparent soil thermal diffusivity. The solution of this equation can be analytical with boundary conditions represented by sinusoidal changes of temperature at the soil surface and average temperatures at the lower boundary. Based on these assumptions two methods for determination of the apparent thermal diffusivity were developed. The first of them is the amplitude equation (Evett 2002):

$$
K_{T}=\frac{\omega}{2} \cdot\left(\frac{z_{2}-z_{1}}{\ln \left(A_{1} / A_{2}\right)}\right)^{2}
$$

where $A_{1}$ is the amplitude at $z_{1}, A_{2}$ is the amplitude at $z_{2}, \omega$ is the radial frequency described as $2 \pi / P$ with $P$ equal to the period of the fundamental cycle. This method has the advantage that only four temperature observations (minimum and maximum) at two depths are required for the determination of the apparent thermal diffusivity. The next method in this group is the so called phase equation which is based on recording the time interval between occurrences of maximum temperatures at two depths (Verhoef et al. 1996):

$$
K_{T}=\frac{1}{2 \cdot \omega} \cdot\left(\frac{z_{2}-z_{1}}{\delta t}\right)^{2}
$$

where: $\delta t=t_{2}-t_{1}, t_{1}$ and $t_{2}$ being the times at which maximum temperature occurs at depths $z_{1}$ and $z_{2}$ respectively.

The main disadvantage of this method is the necessity for accurate measurements of the time of occurrence of the maximum temperatures at the two depths.

The next group of methods applied for calculating the thermal diffusivity coefficient, are based on the assumption that soil temperature near the surface can be described by a series of sine and cosine terms according to the following equation (Horton et al. 1983):

$T(t)=T_{a}+\sum_{n=1}^{M}\left[A_{n} \cdot \cos (n \omega t)+B_{n} \cdot \sin (n \omega t)\right]$

where: $T_{a}$ is the mean value of the temperature in period $P, M$ the number of harmonics and $A_{n}$ and $B_{n}$ are the amplitudes. For two harmonics ( $M$ $=2$ ) the apparent thermal diffusivity can be determined from temperature 
measurements at two depths as an line heat source (Jackson and Taylor arctangent equation in the form of 1986):

(Kossowski and Sikora 1978):

$$
K_{T}=\frac{\omega \cdot\left(z_{2}-z_{1}\right)^{2}}{2 \cdot\left\{\arctan \left[\frac{\left(T_{1}-T_{3}\right) \cdot\left(T_{2}^{\prime}-T_{4}^{\prime}\right)-\left(T_{2}-T_{4}\right) \cdot\left(T_{1}^{\prime}-T_{3}^{\prime}\right)}{\left(T_{1}-T_{3}\right) \cdot\left(T_{1}^{\prime}-T_{3}^{\prime}\right)+\left(T_{2}-T_{4}\right) \cdot\left(T_{2}^{\prime}-T_{4}^{\prime}\right)}\right]\right\}^{2}}
$$

where: $T_{1}, T_{2}, T_{3}, T_{4}$ soil temperatures measured at depth $z_{1}$ with time increments equal 6 hours, and values $T_{1}, T_{2}, T_{3}$, $T_{4}$ ' recorded at depth $z_{2}$.

The same assumption enables to establish the logarithmic method, which can be expressed in the form of [Seemann (1979) reported by Horton et al. (1983)]:

$$
T-T_{0}=(Q / 4 \pi \lambda) \cdot \ln \left(t+t^{\prime}\right)+d
$$

where $T_{0}$ is the initial temperature in ${ }^{\circ} \mathrm{C}$; $Q$ is the energy input per unit length of heater per unit time in $\mathrm{W} \cdot \mathrm{m}^{-1}, \lambda$ is the thermal conductivity of the material surrounding the line source in $\mathrm{W} \cdot \mathrm{m}^{-1 .}{ }^{\circ} \mathrm{C}^{-1}$; $t$ is a time correction used to account for the finite dimensions of the heat source

$$
K_{T}=\left[0.0121 \cdot\left(z_{2}-z_{1}\right) / \ln \left[\frac{\left(T_{1}-T_{3}\right)^{2}+\left(T_{2}-T_{4}\right)^{2}}{\left(T_{1}^{\prime}-T_{3}^{\prime}\right)^{2}+\cdot\left(T_{2}^{\prime}-T_{4}^{\prime}\right)^{2}}\right]\right]^{2}
$$

Thermal diffusivity $\left(K_{T}\right)$ can also be calculated as a quotient between measured value of thermal conductivity $(\lambda)$ and value of volumetric heat capacity $\left(C_{v}\right)$. The parameter $\lambda$ can be measured using non-steady state single probe method. In this method, an electrical wire (probe) is inserted in the soil. A steady current is supplied to the probe and the temperature rise of the heat element is measured by a thermocouple and recorded during a short heating time period (approximately $100 \mathrm{~s}$ ). The temperature $(T)$ of the probe during heating is related to the time $t$ according to the analytical solution for an infinite and the contact resistance between the heat source and the medium outside the source and $d$ is a constant. Assuming that during heating the relation between temperature $(T)$ of the heat element and $\ln (t)$ is linear the thermal conductivity can be expressed in the following form (Hukseflux 2003):

$$
\lambda=(Q / 4 \pi \Delta T) \cdot \ln \left(t_{2} / t_{1}\right)
$$

The volumetric heat capacity $\left(C_{v}\right)$ can be determined using a simple relation implemented by Weiss et al. (2006):

$$
C_{v}=C_{m} \rho+C_{w} \rho_{w} \theta
$$


where $C_{v}$ is the volumetric heat capacity $\left(\mathrm{J} \cdot \mathrm{m}^{-3} \cdot{ }^{\circ} \mathrm{C}^{-1}\right), \mathrm{C}_{\mathrm{m}}$ is the specific heat of organic material equal $1.7\left(\mathrm{~J} \cdot \mathrm{g}^{-1} \cdot{ }^{\circ} \mathrm{C}^{-1}\right)$, $\rho$ is the soil bulk density $\left(\mathrm{g} \cdot \mathrm{cm}^{-3}\right), C_{w}$ is the specific heat of water $4.2\left(\mathrm{~J} \cdot \mathrm{g}^{-1}\right.$. $\left.{ }^{\circ} \mathrm{C}^{-1}\right), \rho_{w}$ is the water density $\left(\mathrm{g} \cdot \mathrm{cm}^{-3}\right)$, $\theta$ is the volumetric soil water content $\left(\mathrm{cm}^{3} \cdot \mathrm{cm}^{-3}\right)$.

\section{MATERIAL}

The laboratory measurements of thermal conductivity were performed for three undisturbed soil monoliths (diameter 11.3 $\mathrm{cm}$ and height $16 \mathrm{~cm}$ ). The soil samples were collected horizontally from the top layer $(5$ to $15 \mathrm{~cm})$ of peat soil profile located at the Biebrza experimental station. After saturation the Non Steady State Probe TP02 was installed in the horizontally oriented soil samples. This measurement setup was placed on the balance. The soil thermal conductivity measurements were performed at daily intervals on monoliths replicated six times. The volumetric moisture contents were also determined simultaneously once a day. The moisture content was calculated from the loss of water from the soil samples due to evaporation. Based on these measured data the functional relation between soil volumetric water content and thermal conductivity coefficient was established.

Figure 1 presents an example of temperature distribution of heat element during the heating period for wet and dry organic material from analysed soil layer.

The field measurements focused on temperature distribution in the topsoil layer. For this purpose, temperature sensors were installed horizontally in the soil profile at 3 and $10 \mathrm{~cm}$ depths. The temperatures were recorded at hourly intervals during the growing season in 2008. Additionally the meteorological conditions were monitored by measuring the average value of air temperature near the soil surface and the daily sums of precipitation. These measurements were conducted from 1st of April to 30th of September 2008. Based on temperature data the apparent thermal diffusivity $\left(K_{T}\right)$

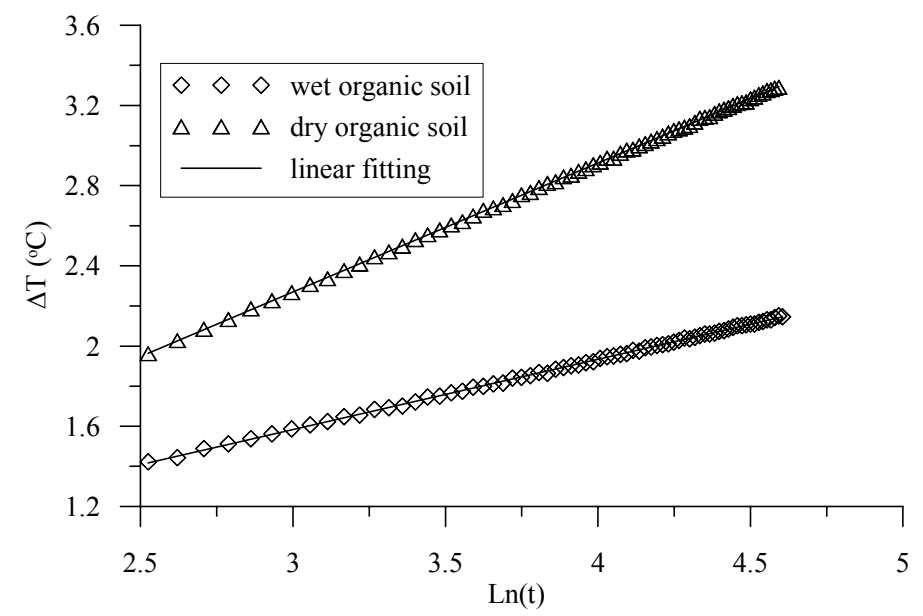

FIGURE 1. Temperature increases in heating sensor 
coefficients were calculated by applying the amplitude, phase, arctangent and logarithmic equations. The calculations of $K_{T}$ data were performed for days with equal average temperatures for each measurement depths.

\section{RESULTS AND DISCUSSION}

Soil conditions during the growing season period can be expressed using moisture and temperature regimes. The average moisture content (top $10 \mathrm{~cm}$ ) at the beginning of vegetation in 2008 was equal to $65 \%$. Then the soil water content gradually decreased until the 6th of June (67 day of vegetation) when the first cutting of the grass community was carried out (Fig. 2). This tendency was related to the plant water consumption and evaporation. After cutting the moisture content was very low and approximately equal to $27 \%$. The moisture status changed on the 95 th day of the start of vegetation when a very high precipitation event occurred (Fig. 2 ). This caused the soil moisture content to increase and the intensive start of the next stage of plant development. During the last two months of vegetation the soil water retention slowly increased mainly due to precipitation events.
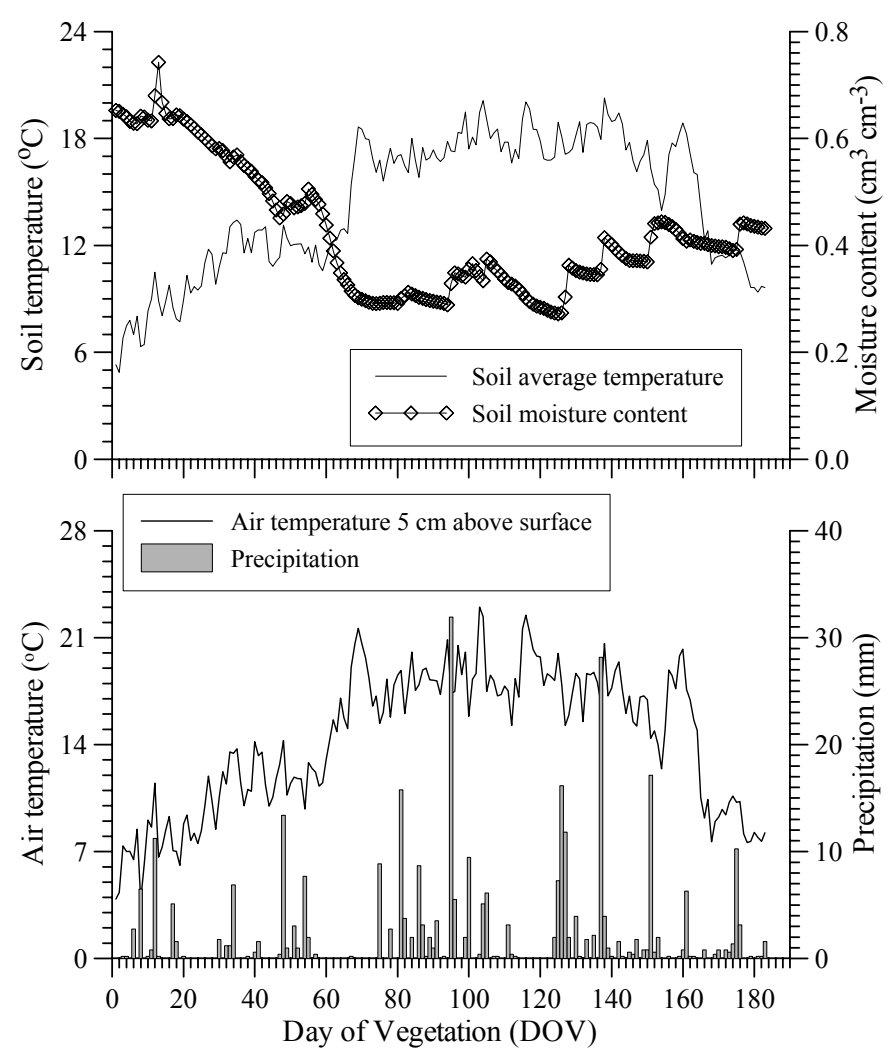

FIGURE 2. The soil moisture content, temperature regimes and precipitation in vegetation season of 2008 
Together with the soil moisture status the soil temperatures were monitored continuously in the topsoil layer. At the beginning of vegetation, the average temperature in the topsoil layer was relatively low and approximately equal to $7^{\circ} \mathrm{C}$. It subsequently increased continuously but its value was not higher than $14^{\circ} \mathrm{C}$. After the first grass cutting the soil temperature increased instantly and reached about $19^{\circ} \mathrm{C}$. This was due to the reduction in the height of the grass community which acted as an insulation layer.

During the second stage of vegetation the soil temperature increased very slowly but gradually which was probably caused only by climatic conditions. In the last month of the growing season, soil temperature was significantly related to the air temperature changes. The plot of moisture content and temperature in the upper soil layer show that their seasonal changes are correlated to each other and depend mainly on the stage of vegetation. The data presented indicate that soil temperature and water content dynamics during the first stage of plant developments (first cut) can be used to determine the field thermal properties of organic topsoil layer. It is also possible to study of the dependence of $K_{T}$ on moisture content.

As mentioned above, the distribution of soil temperature at two depths is required for the determination of thermal diffusivity under field condition. The main assumption in the calculation methods is that the average temperature at the two measurement depths should be equal (Horton et al. 1983, Kossowski and Sikora 1978). Therefore, in order to fulfill this criterion, the average soil temperature at the two measurement depths was calculated for each day of the vegetation period. For days with equal average temperatures, the thermal diffusivity coefficients were then determined using the methods described in the previous section and commonly referred to as: amplitude, phase, arctangent and logarithmic equations. The moisture contents for each of the selected days were also used for data analysis. The results of thermal diffusivity $\left(K_{T}\right)$ calculation and moisture content measurements are plotted in Figure 3. The data show that $K_{T}$ values determined using the logarithmic and amplitude equations follow the changes in soil moisture content. This tendency suggests that apparent thermal diffusivity is a function of moisture content. The $K_{T}$ data calculated with the arctangent and especially the phase equations are more scattered. In these cases, the correlation between soil moisture content and thermal diffusivity is unclear. Moreover the thermal diffusivity determined using the phase equation is generally lower than that determined using the other methods.

This is probably a result of the hourly measurements of the soil temperatures what influence on the $K_{T}$ determination using the phase equation. For a more precisedetermination ofintervals between maximum temperatures occurrences at the two depths, a time step lower then one hour is probably required.

As mentioned above, the thermal diffusivity of the soil can also be calculated on the basis of independent measurements of thermal conductivity $(\lambda)$ and volumetric heat capacity $\left(C_{v}\right)$. In the laboratory the $\lambda$ values were 

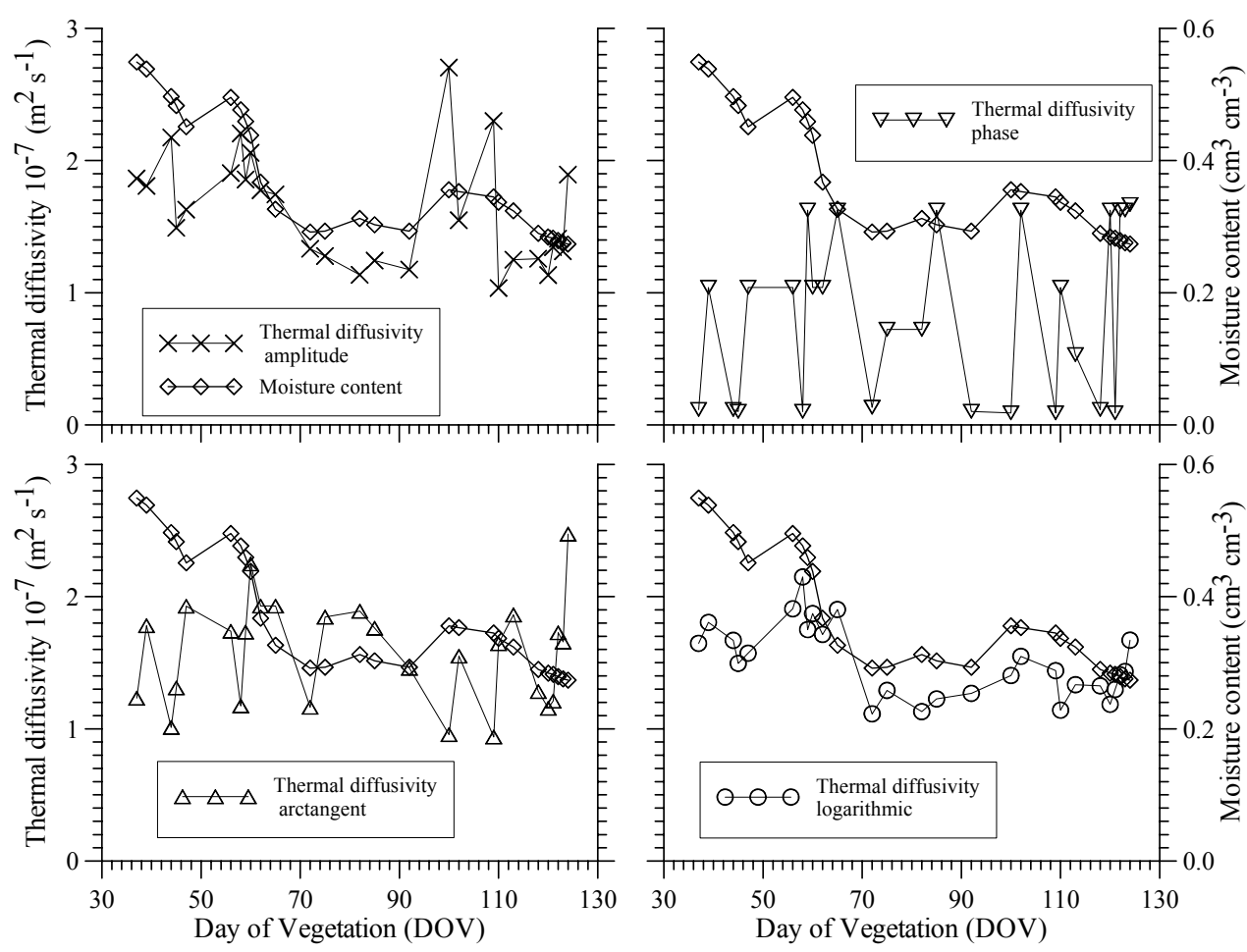

FIGURE 3. Field thermal diffusivity and soil moisture content of analyzed organic soil layer

measured using the single needle probe (Hukseflux 2003). The average values of thermal conductivity and their standard deviations as a function of soil moisture content are plotted in Figure 4a. The measured values of the thermal conductivity of the organic soil layer are varying between 0.12 to approximately $0.6\left(\mathrm{~W} \cdot \mathrm{m}^{-1.0} \mathrm{C}^{-1}\right)$. The data show that the value of $\lambda$ is decreasing with decreasing moisture content (Fig. 4). The relationship between these measured physical properties is statistically significant and can be expressed in the form of (Scheatzl et al. 1994):

$$
\lambda(\theta)=a+b \cdot \exp (-c / \theta)
$$

where:

$\lambda$ - thermal conductivity $\left(\mathrm{W} \cdot \mathrm{m}^{-1} \cdot{ }^{\circ} \mathrm{C}^{-1}\right)$, $\theta$ - soil moisture content $\left(\mathrm{cm}^{3} \cdot \mathrm{cm}^{-3}\right)$, $a$ - parameter which expresses the thermal conductivity at $\theta=0\left(\mathrm{~W} \cdot \mathrm{m}^{-1}\right.$. ${ }^{\circ} \mathrm{C}^{-1}$ ),

$b, c$ - shape parameters $\left(\mathrm{W} \cdot \mathrm{m}^{-1} \cdot{ }^{\circ} \mathrm{C}^{-1}\right)$, $(-)$.

The parameters of equation (10) were determined by fitting the equation to the average measured thermal conductivity data. Their values were identified by minimization of the sum of the squared differences between measured and calculated values of $\lambda$. The optimization procedure lead to the following values of parameters: $a=0.119\left(\mathrm{~W} \cdot \mathrm{m}^{-1} \cdot{ }^{\circ} \mathrm{C}^{-1}\right)$, 


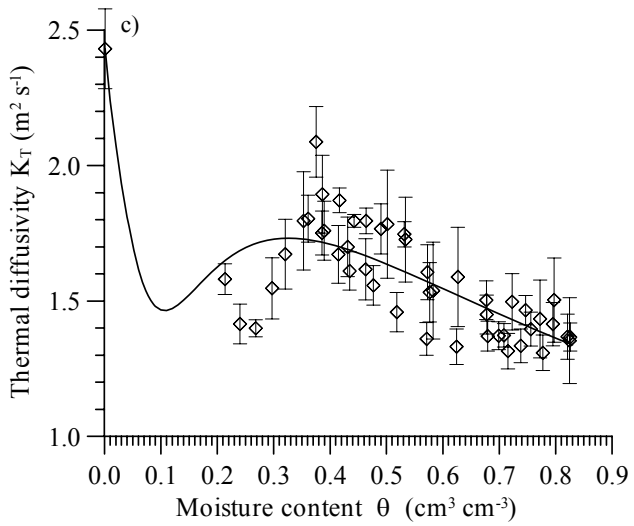

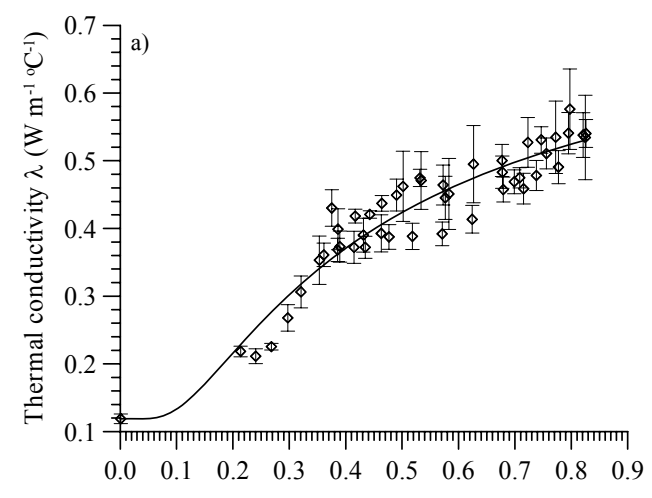

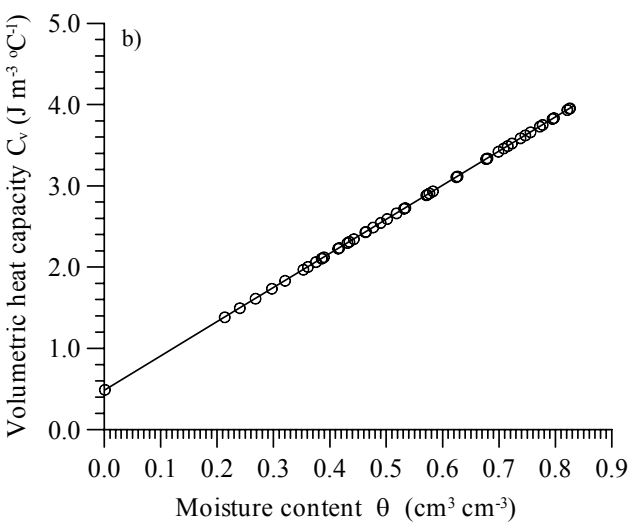

FIGURE 4. Thermal properties of analyzed soil: a) thermal conductivity, b) volumetric heat capacity and c) thermal diffusivity

$\mathrm{b}=0.653\left(\mathrm{~W} \cdot \mathrm{m}^{-1} \cdot{ }^{\circ} \mathrm{C}^{-1}\right)$ and $\mathrm{c}=0.381(-)$. The coefficient of determination of this relationship between $\lambda$ and $\theta$ is high and equal to $90 \%$ as shown by the fit between the curve and the data in Figure 4a.

For each of the measured value of thermal conductivity the corresponding values of volumetric heat capacity were calculated using equation (9). For this purpose the specific heat capacity $\left(C_{p}\right)$ in equation (9) was assumed to be 1.7 $\left(\mathrm{J} \cdot \mathrm{g}^{-1}\right)$ which was applied by Weiss et al. (2006). Although the $C_{p}$ value should be measured independently, it was assumed for this study that the value equal to 1.7 $\left(\mathrm{J} \cdot \mathrm{g}^{-1}\right)$ was generally valid for organic soils. According to the assumptions expressed in the form of equation (9), the volumetric heat capacity is linearly related to volumetric soil moisture content. The linear variation of $C_{v}$ as a function of $\theta$ for the soil studied is presented in Figure $4 \mathrm{~b}$. The minimum calculated volumetric heat capacity zero moisture content rising to 3.95 $10^{6}\left(\mathrm{~J} \cdot \mathrm{m}^{-3} \cdot{ }^{\circ} \mathrm{C}^{-1}\right)$ at full capacity for the organic soil considered here.

The set of measured values of thermal conductivity and calculated values of volumetric heat capacity was used to determine thermal diffusivity. This was done by dividing each $\lambda$ value (including standard deviations) by the corresponding is equal to $0.4887 \cdot 10^{6}\left(\mathrm{~J} \cdot \mathrm{m}^{-3} \cdot{ }^{\circ} \mathrm{C}^{-1}\right)$ at 
$C_{v}$ value for a given moisture content. The results of the calculations are presented in Figure 4c. The solid line in this Figure was established by dividing fitted thermal conductivity data (solid line Fig. 4a) by fitted values of $C_{v}$ (solid line Fig. $4 b)$.

The thermal diffusivity values obtained experimentally were then compared to those obtained using the amplitude, phase, arctangent and logarithmic equations for soil moisture contents ranging from 27 to $54 \%$. This corresponded to sets of 25 values of thermal diffusivity for each method which were compared using basic population statistics. The average, minimum, maximum, standard deviation and coefficient of variation $(\mathrm{CV})$ values of the estimated thermal diffusivities for each method are presented in Table 1. Table 1 show that the average thermal diffusivity determined by applying the phase equation is approximately two times lower than average values calculated with the other methods. The $K_{T}$ data obtained by measuring thermal conductivity (method indicated in Table 1 as $\lambda / C_{v}$ ) show the lowest variations. An increasingly higher variability is obtained for the thermal diffusivity determined using the logarithmic, arctangent and amplitude methods, respectively. The phase equation leads to the highest variability as well as the highest standard deviation in calculated $K_{T}$ data.

The apparent thermal diffusivity determined by the five different methods presented in Table 1 was also compared using analysis of variance. Least significant differences (LSD) were calculated using the Statgraphics plus software (STSC 1996). The results of the analysis are shown in the Figure 5. This shows that the mean value of thermal diffusivity is similar for four of the analyzed methods. The mean $K_{T}$ value calculated using the phase equation is significantly lower than that obtained with the other four methods. The LSD $(p=0.05)$, which is equal to $2.275 \cdot 10^{-8}$ $\left(\mathrm{m}^{2} \cdot \mathrm{s}^{-1}\right)$, indicates that the analyzed data are divided into two homogenous groups. The first group represent $K_{T}$ values determined using the phase equation whereas the second group includes the data calculated using the rest of the methods.

The thermal diffusivity values calculated using the amplitude, phase, arctangent and logarithmic equations are plotted as a function of water contents in the Figure 6. In addition, the relationship between thermal diffusivity and moisture content obtained using the laboratory measurements of thermal conductivity (i.e. Fig. 4c) is also plotted as a solid line in Figure 6. The data obtained

TABLE 1. Comparison between thermal diffusivity data estimated using different methods

\begin{tabular}{|l|c|c|c|c|c|}
\hline \multirow{2}{*}{ Statistics } & \multicolumn{4}{|c|}{ Equation } & \multirow{2}{*}{$\lambda / \mathrm{C}_{\mathrm{v}}$} \\
\cline { 2 - 5 } & Amplitude & Phase & Arctangent & Logarithmic & \\
\hline Average $\left(\mathrm{m}^{2} \cdot \mathrm{s}^{-1}\right)$ & $1.60 \mathrm{E}-07$ & $8.21 \mathrm{E}-08$ & $1.56 \mathrm{E}-07$ & $1.50 \mathrm{E}-07$ & $1.69 \mathrm{E}-07$ \\
\hline Standard deviation & $4.35 \mathrm{E}-08$ & $6.30 \mathrm{E}-08$ & $3.62 \mathrm{E}-08$ & $2.84 \mathrm{E}-08$ & $1.63 \mathrm{E}-08$ \\
\hline Minimum & $1.04 \mathrm{E}-07$ & $8.99 \mathrm{E}-09$ & $9.39 \mathrm{E}-08$ & $1.11 \mathrm{E}-07$ & $1.36 \mathrm{E}-07$ \\
\hline Maximum & $2.70 \mathrm{E}-07$ & $1.62 \mathrm{E}-07$ & $2.25 \mathrm{E}-07$ & $2.15 \mathrm{E}-07$ & $2.09 \mathrm{E}-07$ \\
\hline CV $(\%)$ & 27.13 & 76.79 & 23.30 & 19.00 & 9.62 \\
\hline
\end{tabular}




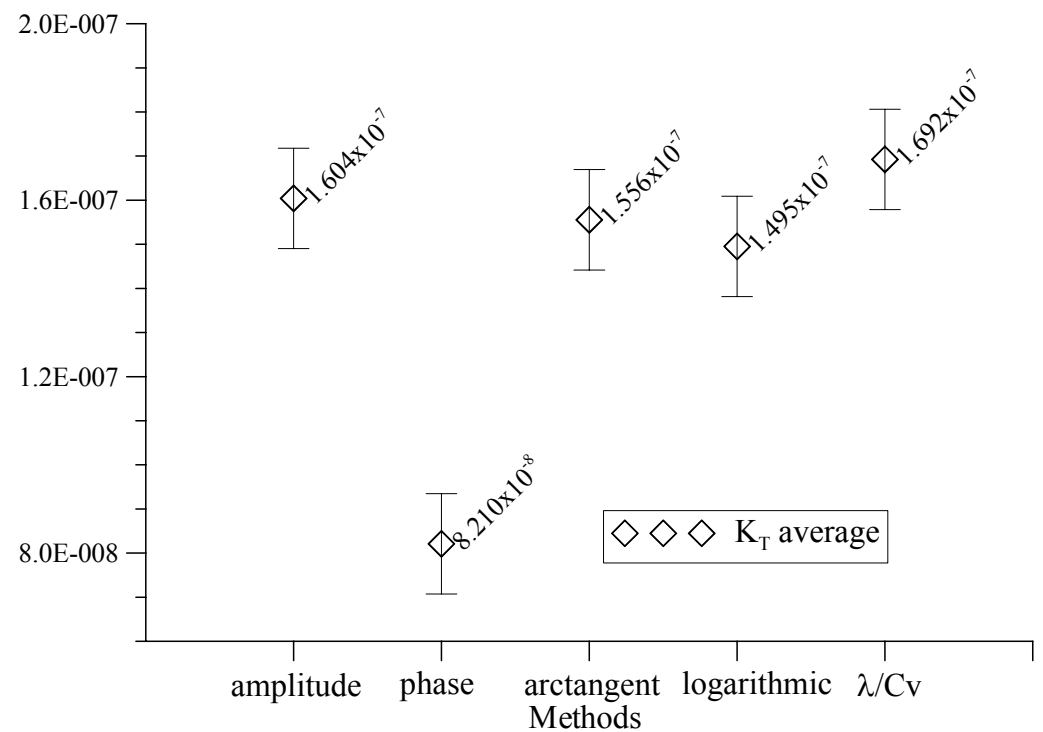

FIGURE 5. Average thermal diffusivity and LSD values
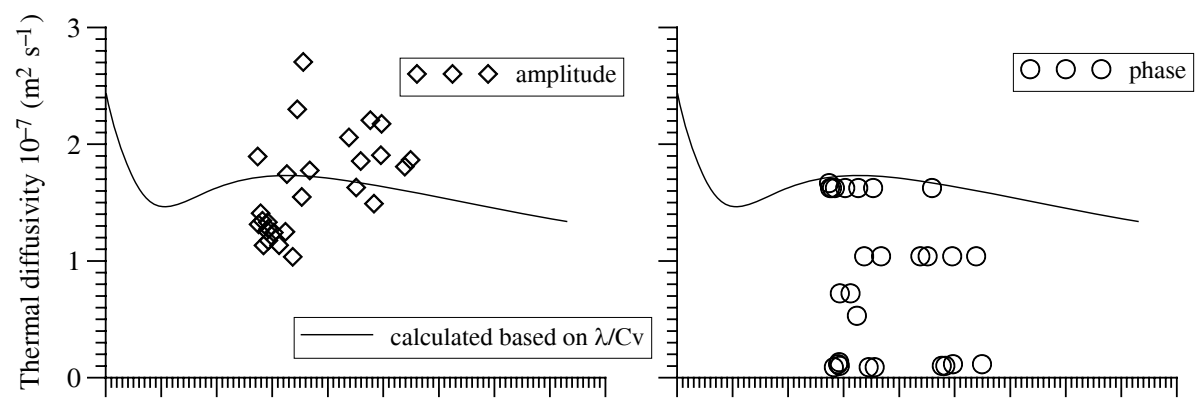

再 $3 \exists$

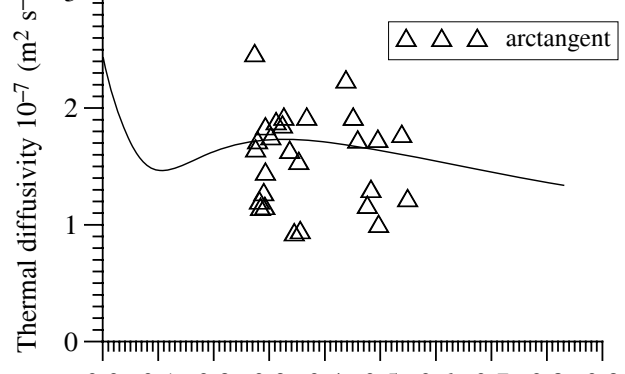

$\begin{array}{llllllllll}0.0 & 0.1 & 0.2 & 0.3 & 0.4 & 0.5 & 0.6 & 0.7 & 0.8 & 0.9\end{array}$

Soil moisture content $\left(\mathrm{cm}^{3} \cdot \mathrm{cm}^{-3}\right)$

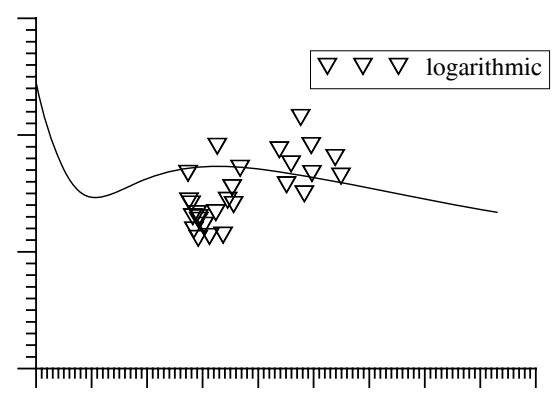

$\begin{array}{llllllllll}0.0 & 0.1 & 0.2 & 0.3 & 0.4 & 0.5 & 0.6 & 0.7 & 0.8 & 0.9\end{array}$

Soil moisture content $\left(\mathrm{cm}^{3} \cdot \mathrm{cm}^{-3}\right)$

FIGURE 6. Thermal diffusivity data as a function of water content for organic soil layer 
analytically with the four equations can be compared to those obtained with thermal conductivity measurements by calculating the sum of the squared differences (SSQ). The minimum value of SSQ is obtained for data estimated using the logarithmic equation and is equal to $3.42 \cdot 10^{-14}$. In comparison, the highest SSQ was obtained for the thermal diffusivity values determined using the phase equation and was equal to $3.13 \cdot 10^{-13}$.

\section{SUMMARY AND CONCLUSIONS}

Thermal diffusivity is a key parameter required for the study of thermal processes in soils. In this study, thermal diffusivity was quantified using different methods. The first group of methods considered included calculation procedures developed from analytical solution of the heat transfer equation. For these methods the determination of thermal diffusivity required knowledge of the distribution of the soil temperature at two different depths. The second type of method used to determine thermal diffusivity was based on the experimental quantification of thermal conductivity and knowledge of heat capacity.

The first type of methods of calculation consisted of four equations referred to as: amplitude, phase, arctangent and logarithmic equations. The apparent thermal diffusivity obtained with the logarithmic amplitude and arctangent equations were comparable whereas the $K_{T}$ data estimated using the phase equation were significantly lower and highly variable compared to the other methods. Based on the results of this study, the logarithmic and amplitude equations seem more appropriate for the calculation of thermal diffusivity of organic topsoil layers. However these methods should be validated with other data sets and proper selection of temperature series for calculation should be performed. Based on this study, the phase equation does not seem to be an appropriate method for thermal diffusivity determination for organic soils. This investigation also showed that field thermal diffusivity is potentially dependent on moisture content although the statistical significance of this relation was low. Estimation of thermal diffusivity using the second type of method seems attractive because some of the required parameters such as thermal conductivity $(\lambda)$ can be measure in the laboratory under controlled boundary conditions. However, for this method the quantification of volumetric heat capacity is also needed. Comparisons between the two types of approaches indicate that they lead to comparable thermal diffusivity results. Although this study provides a valuable comparison between the different methods, further research is needed to investigate the influence of temperature measurement depth and moisture content on the determination of thermal diffusivity using the methods presented here.

\section{REFERENCES}

ABU-HAMDEH N.H. 2001: Measurement of the thermal conductivity of sandy loam and clay loam soil using and dual probes. J. Agric. Engng. Res. 80 (2) 209-216.

BRISTOW K.L.,WHITE R.D., KLUITENBERG G.L. 1994: Comparison of single 
and dual-probes for measuring soil thermal properties with transient heating. Australian Journal of soil reserch, 32, 447-464.

De VRIES D.A. 1963: Thermal properties of soils. In W.R. van Wijk (ed.), Physics of plant environment pp. 210-235 NorthHolland, Amsterdam.

EVETT S.R. 2002: Water and energy balances at soil-plant-atmosphere interfaces In: Soil Physics Companion (A.W. Warrick ed.), CRC Press, Boca Raton, Florida (USA): 127-183.

GNATOWSKI T., SZATYŁOWICZ J., SZEJBA D., BRANDYK T., OLESZCZUK R. 2006: Thermal diffusivity of a moorsh layer. [W:] T. Brandyk, L. Szajdak, J. Szatyłowicz (red.) „Właściwości fizyczne i chemiczne gleb organicznych", Wyd. SGGW, s. 175-184.

HORTON R., WIERENGA P.J., NIELSEN D.R. 1983: Evaluation of methods for determining the apparent thermal diffusivity of soil near the surface. Soil Sci. Soc. Am. J., vol. 47: 25-32.

HUBRECHTS L. 1988: Transfer functions for the generation of thermal properties of Belgian soils. Dissertationes de Agricultura Nr. 372., Katholike Universiteit Leuven., 236 pp.

Hukseflux; 2003: Thermal sensors. User Manual version 0301 i 0304

JAKCSON R.D., TAYLOR S.A., 1986: Thermal conductivity and diffusivity. In: A. Klute (ed.) Methods of soil analysis. Part 1. 2nd ed., pp. 945-956 Agronomy Monographs 9, ASA and SSSA, Madison, Wisconsin, USA.

JURY W.A., GARDNER W.R., GARDNER W.H. 1991: Soil physics $5^{\text {th }}$ ed. John Wiley \& Sons 173-195.

KOSSOWSKI J., SIKORA E. 1978: Thermal properties of the soils and methods of their determination. Problemy Agrofizyki, zeszyt 27 s. 58.

SCHAETZL R.J., BARETT L.R., WINKLER J.A. 1994: Choosing models of soil chronofunctions and fitting them to data. Europen Journal of Soil Sci. 45: 219-232.

STSC-Inc.-Statistical Graphics Corporation, 1996. STATGRAPHICS Plus - Statistical Graphics System - ver. 2.1, Rockvile, Maryland, USA.

USOWICZ B. 1996: Thermal properties of selected horticultural substrates. Zesz. Probl. Post. Nauk Rol. z. 429: 305-313.

USOWICZ B. 1992: Statistical-physical model of thermal conductivity in soil. Polish Journal of Soil Sciences Vol. XXV/1 pp. 25-34.

VERHOEF A., HURK VAN DEN B.J.J.M., JACOBS A.F.G., HEUSINKVELD B.G. 1996: Thermal soil properties for vineyard (EFEDA-I) and savanna (HAPEX-Sahel) sites. Agricultural and Forest Meteorology, 78: 1-18.

WEISS R., SHURPALIN.J., SALLANTAUS T., LAIHO R., LAINE J. and ALM J. 2006: Simulation of water table level and peat temperatures in boreal peatlands. Ecological Modelling 192, 441-456.

Streszczenie. Analiza wspótczynnika dyfuzyjności termicznej dla wybranego przypowierzchniowego utworu organicznego. Współczynnik dyfuzyjności termicznej $K_{T}$ jest kompleksową właściwością fizyczną gleby. Wynika to z faktu, iż parametr ten jest ilorazem współczynnika przewodności termicznej i objętościowej pojemności cieplnej. W glebach organicznych wartości współczynnika $K_{T}$ są słabo rozpoznane. Celem pracy była ocena współczynnika dyfuzyjności termicznej wybranego utworu organicznego przy zastosowaniu różnych metod obliczeniowych i pomiarowych. W grupie metod obliczeniowych zastosowano równania: amplitudy, fazy, arcustangens oraz logarytmiczne. Metody te opracowane zostały na podstawie analitycznego rozwiązania równania przewodnictwa cieplnego. Do opracowania współczynnika $K_{T}$ wymagane są godzinowe wartości temperatur pomierzone na dwóch głębokościach w profilu glebowym. Druga grupa metod związana jest z definicją współczynnika dyfuzyjności termicznej w myśl, której do określenia współczynnika $K_{T}$ konieczna jest znajomość wartości współczynnika przewodności termicznej $(\lambda)$ i objętościowej pojemności cieplnej $\left(C_{v}\right)$. Do po- 
miaru współczynnika $\lambda$ zastosowano metodę stanu nieustalonego przy zastosowaniu sondy NSSP Hukseflux, natomiast wartości $C_{v}$ obliczono przy zastosowaniu formuły empirycznej. Na podstawie uzyskanych wyników pomiarów i obliczeń można stwierdzić, że równanie fazy ma ograniczone zastosowanie do określania wartości $K_{T}$ $\mathrm{w}$ przypowierzchniowych utworach organicznych. Pozostałe cztery analizowane w pracy metody określania współczynnika dyfuzyjności termicznej są porównywalne. Przeprowadzone badania wskazują na przydatność stosowanych metod pomiarowych do oceny współczynnika dyfuzyjności termicznej utworów organicznych. Jednakże konieczne jest przeprowadzenie badań uzupełniających mających na celu zbadanie wpływu temperatur pomierzonych na różnych głębokościach w profilu glebowym na wartości współczynnika dyfuzyjności termicznej.

\section{Acknowledgement}

The work was supported by the Polish Ministry of Science (research project no N305 015 32/0954, 2007-2009)

MS. received-November 2009

\author{
Author's address: \\ Tomasz Gnatowski \\ Katedra Kształtowania Środowiska SGGW \\ w Warszawie \\ ul. Nowoursynowska 159 \\ 02-776 Warszawa \\ e-mail: tomasz_gnatowski@sggw.pl
}

